\title{
OPTIMALISASI MODEL PEMBELAJARAN PROBLEM BASED LEARNING (PBL) MENGGUNAKAN OFFICE 365 UNTUK MENINGKATKAN HASIL BELAJAR SOSIOLOGI MATERI PERBEDAAN, KESETARAAN, DAN HARMONI SOSIAL DI KELAS XI IPS SMA NASIMA SEMARANG
}

Oleh:

Eni Setyaningsih ${ }^{1}$

\begin{abstract}
Abstrak
Pada masa Pembelajaran Jarak Jauh (PJJ) beberapa permasalahan muncul karena kurang terjalinnya komunikasi dua arah sehingga memberikan dampak pada rendahnya hasil belajar peserta didik terutama pada mata pelajaran sosiologi. Penelitian Tindakan Kelas (PTK) ini bertujuan untuk meningkatkan hasil belajar sosiologi pada materi perbedaan, kesetaraan, dan harmoni sosial di kelas XI IPS SMA Nasima Semarang dengan menggunakan microsoft 365 atau juga disebut sebagai office 365. Subyek penelitian ini adalah kelas XI IPS yang berjumlah 19 peserta didik. Teknik pengumpulan data yang digunakan dalam penelitian ini adalah dengan tes hasil belajar dan lembar observasi yang dilaksanakan dalam pratindakan, siklus I, dan siklus II. Data yang terkumpul dianalis dengan menggunakan analisis kuantitatif dan kualitatif. Hasil penelitian ini menunjukkan bahwa nilai ketuntasan klasikal peserta didik kelas XI IPS SMA Nasima Semarang pada tahap pra tindakan adalah 52,63\% dengan nilai rata-rata kelas 68,68. Pada siklus I nilai ketuntasan klasikal peserta didik menjadi 78,95\% dengan rata-rata kelas 78,1 , sedangkan pada siklus II nilai ketuntasan klasikal peserta didik menjadi $100 \%$ dengan rata-rata kelas 89,68 . Dari data tersebut dapat disimpulkan bahwa optimalisasi model pembelajaran problem based learning dengan menggunakan office 365 dapat meningkatkan hasil belajar sosiologi materi perbedaan, kesetaraan, dan harmoni sosial di kelas XI IPS SMA Nasima Semarang.
\end{abstract}

Kata Kunci: Hasil Belajar; Office 365; Problem Based Learning; Sosiologi

${ }^{1}$ Guru Sosiologi, SMA Nasima Semarang, email: enisetya23@gmail.com 
Habitus: Jurnal Pendidikan Sosiologi dan Antropologi

Vol. 4 No. 1 Tahun 2020 hal. 70-79

ISSN: 2597-9264

\section{PENDAHULUAN}

Sejalan dengan perkembangan abad 21, yang dikenal dengan era globalisasi maka diperlukan profesionalisme di segala bidang termasuk dunia pendidikan. Permasalahan yang mengemuka dalam dunia pendidikan adalah bagaimana suatu proses pembelajaran dirancang dan diturunkan dalam praktek. Baik dan buruknya kualitas pendidikan sangat berhubungan dengan kinerja guru dalam menjalankan profesinya sebagai pembelajar. Dalam ruang ini, seorang guru selalu ditantang untuk dapat menemukan format yang tepat dan memformulasikan dalam strategi yang taktis suatu rancangan pembelajaran yang mencerahkan (Parman, 2005 : 9).

Berangkat dari hal tersebut, perlu ditemukan cara terbaik untuk menyampaikan konsep yang diajarkan di dalam mata pelajaran Sosiologi, sehingga siswa dapat menggunakan dan mengingat lebih lama konsep-konsep tersebut sebagai suatu kompetensi yang berguna. Di samping itu, guru dituntut kemampuannya untuk berkomunikasi secara efektif dengan siswanya. Konsekuensi logis dari tuntutan profesionalitas ini adalah kemampuan menemukan pendekatan dan strategi pembelajaran yang tepat sesuai dengan kekhasan mata pelajaran Sosiologi. Dalam kedudukannya sebagai sebuah disiplin ilmu sosial, secara teoritik idealnya Sosiologi memiliki posisi strategis dalam membahas dan mempelajari masalah-masalah sosial yang berkembang di masyarakat. Karenanya, pengajaran Sosiologi perlu semakin tanggap dan sensitif terhadap perkembangan di masyarakat dan selalu siap dengan pemikiran kritis dan alternatif menjawab tantangan yang ada.

Pengajaran Sosiologi di Sekolah Menengah Atas berfungsi untuk meningkatkan kemampuan berfikir, berperilaku, dan berinteraksi dalam keragaman realitas sosial dan budaya berdasarkan etika. Tujuan pengajaran sosiologi pada dasarnya mencakup dua sasaran yang bersifat kognitif dan bersifat praktis. Secara kognitif pengajaran sosiologi dimaksudkan untuk memberikan pengetahuan dasar sosiologi agar siswa mampu memahami dan menelaah secara rasional komponen-komponen dari individu, kebudayaan dan masyarakat sebagai suatu sistem. Sementara itu 
Habitus: Jurnal Pendidikan Sosiologi dan Antropologi

Vol. 4 No. 1 Tahun 2020 hal. 70-79

ISSN: 2597-9264

sasaran yang bersifat praktis dimaksudkan untuk mengembangkan keterampilan sikap dan perilaku siswa yang rasional dan kritis dalam menghadapi kemajemukan masyarakat, kebudayaan, situasi sosial serta berbagai masalah sosial yang ditemukan dalam kehidupan sehari-hari.

Model pembelajaran berbasis masalah (Problem-Based Learning) adalah suatu model pembelajaran yang menggunakan masalah dunia nyata sebagai konteks bagi peserta didik untuk belajar tentang cara berfikir kritis dan keterampilan memecahkan masalah. Dengan asumsi dasar pada batasan masalah tersebut, Problem-Based Learning (PBL) menjadi relevan untuk diterapkan sebagai strategi pembelajaran Sosiologi. Dengan pendekatan PBL diasumsikan belajar Sosiologi akan menjadi menarik karena objek yang dipelajari situasi dunia nyata yang dekat dengan kehidupan peserta didik.

Untuk menjalin komunikasi dua arah, penggunaan office 365 sebagai media pembelajaran sangat membantu guru dan peserta didik dalam menerapkan pembelajaran dengan model problem based learning (PBL). Office 365 dapat diakses bersamaan sehingga sangat relevan digunakan peserta didik dan dapat dipantau langsung oleh guru terkait keaktifan peserta didik saat diskusi kelompok berlangsung.

Dalam hal ini peneliti selaku guru pengajar telah melakukan observasi di kelas XI IPS SMA Nasima Semarang. Di kelas tersebut memiliki jumlah peserta didik 19 peserta didik dengan komposisi 13 putra dan 6 putri. Dalam kegiatan observasi ditemukan berbagai masalah yang timbul dalam proses pembelajaran. Masalahmasalah dalam proses pembelajaran tersebut bisa muncul dari pihak guru, peserta didik maupun interaksi dari keduanya. Masalah yang timbul dalam pembelajaran terutama saat PJJ daring antara lain kurangnya minat belajar peserta didik terhadap mata pelajaran sosiologi juga menjadi suatu masalah yang membuat rendahnya partisipasi peserta didik dalam proses pembelajaran. Selain itu, rendahnya partisipasi aktif selama daring disebabkan karena mereka tidak memiliki keberanian untuk menyampaikan pendapat mereka sendiri dan memilih diam. Selain masalah dari pihak peserta didik terdapat beberapa 
Habitus: Jurnal Pendidikan Sosiologi dan Antropologi

Vol. 4 No. 1 Tahun 2020 hal. 70-79

ISSN: 2597-9264

masalah yang memang bersumber dari guru itu sendiri misalkan guru yang tidak menggunakan metode dalam proses pembelajaran. Penggunaan metode pembelajaran berperan sangat penting untuk kelanjutan proses pembelajaran, karena dengan menggunakan berbagai metode dalam proses pembelajaran itu mampu membuat proses pembelajaran lebih bervariasi. Dari berbagai masalah yang timbul dalam proses pembelajaran tersebut secara langsung dapat mempengaruhi hasil belajar peserta didik. Berdasarkan latar belakang di atas peneliti tertarik untuk melakukan Penelitian Tindakan Kelas (PTK) dengan judul "OPTIMALISASI MODEL PEMBELAJARAN PROBLEM BASED LEARNING (PBL) MENGGUNAKAN $\begin{array}{lll}\text { OFFICE } & 365 & \text { UNTUK }\end{array}$ MENINGKATKAN HASIL BELAJAR SOSIOLOGI MATERI PERBEDAAN, KESETARAAN, DAN HARMONI SOSIAL DI KELAS XI IPS SMA NASIMA SEMARANG”.

\section{METODE PENELITIAN}

Penelitian ini menggunakan Penelitian Tindakan Kelas (PTK). Subyek penelitian adalah peserta didik kelas XI IPS SMA Nasima Semarang tahun pelajaran 2020/2021 yang berjumlah 19 peserta didik dengan komposisi 13 peserta didik putra dan 6 peserta didik putri. Teknik pengumpulan data menggunakan teknik tes dan non tes. Pengumpulan data dilakukan melalui tes tertulis dan lembar observasi. Tes tertulis digunakan untuk mengetahui hasil belajar kognitif peserta didik. Lembar observasi digunakan untuk mengamati proses belajar peserta didik. Adapun teknik analisis datanya menggunakan teknik analisis data secara kuantitatif untuk data hasil belajar siswa dan teknik analisis data secara kualitatif untuk data lembar observasi guru. Penelitian ini merupakan Penelitian Tindakan Kelas (PTK) yang dilaksanakan dalam 4 (empat) tahap, yaitu perencanaan, tindakan, pengamatan, dan refleksi. Prosedur kerja tersebut secara garis besar dapat dijelaskan pada Gambar 1 di bawah ini. 
Habitus: Jurnal Pendidikan Sosiologi dan Antropologi

Vol. 4 No. 1 Tahun 2020 hal. 70-79

ISSN: 2597-9264

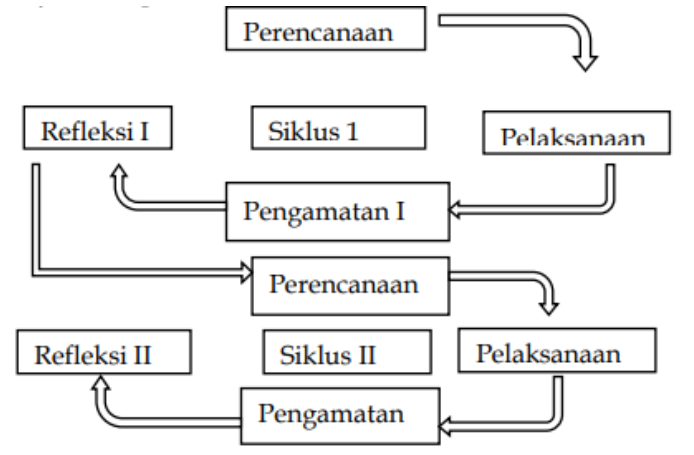

Gambar 1. Model Kemmis dan

McTaggart (Taniredja dkk, 2013)

\section{HASIL}

Peneliti melakukan Penelitian Tindakan Kelas (PTK) di kelas XI IPS SMA Nasima Semarang pada pembelajaran sosiologi materi perbedaan, kesetaraan, dan harmoni sosial dengan model pembelajaran problem based learning menggunakan office 365 sebanyak 3 siklus. Siklus I dilaksanakan pada hari Kamis, 22 Oktober 2020 dan siklus II pada hari Senin, 2 November 2020. Berdasarkan hasil tertulis diperoleh data yang selanjutnya direkapitulasi dan dianalisis berdasarkan hasil belajar peserta didik (kognitif) pada pratindakan, siklus I, dan siklus II seperti disajikan pada Tabel 1.

Tabel 1. Tabel Keseluruhan Hasil Belajar Ranah Kognitif Kelas XI IPS \begin{tabular}{|l|l} 
Tindakan & Ket.
\end{tabular}

\begin{tabular}{|l|c|c|c|l|}
\hline $\begin{array}{l}\text { Hasil } \\
\text { Belajar }\end{array}$ & Pra & $\begin{array}{c}\text { Sikl } \\
\text { us I }\end{array}$ & $\begin{array}{c}\text { Sikl } \\
\text { us II }\end{array}$ & \\
\hline $\begin{array}{l}\text { Ketuntas } \\
\text { an }\end{array}$ & $\begin{array}{c}52, \\
63\end{array}$ & $\begin{array}{c}78,9 \\
5 \%\end{array}$ & $\begin{array}{c}100 \\
\%\end{array}$ & $\begin{array}{l}\text { Meningk } \\
\text { at }\end{array}$ \\
\hline $\begin{array}{l}\text { Nilai } \\
\text { Rata2 }\end{array}$ & $\begin{array}{c}68, \\
68\end{array}$ & 78,1 & $\begin{array}{c}89,6 \\
8\end{array}$ & $\begin{array}{l}\text { Meningk } \\
\text { at }\end{array}$ \\
\hline
\end{tabular}

Dari tabel tersebut dapat kita lihat bahwa peningkatan terjadi pada setiap siklus. Peningkatan dari pratindakan ke siklus I sebesar 26,32\%, dan dari siklus I ke Siklus II mengalami peningkatan sebesar 21,05\%. Jika dibuat dalam bentuk diagram adalah sebagai berikut:

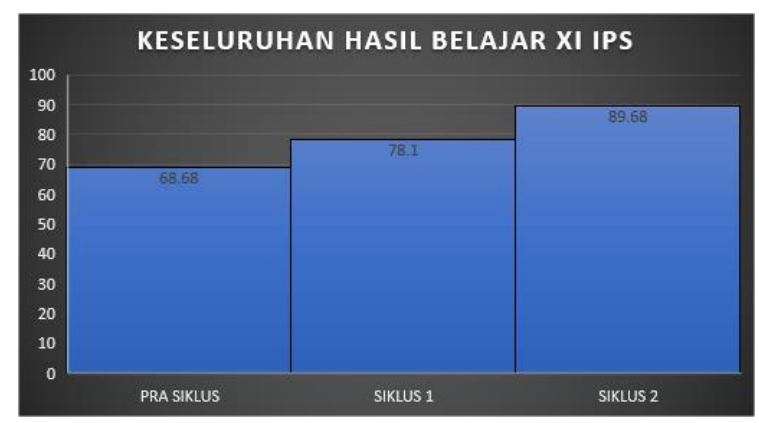

Gambar 2. Keseluruhan Hasil Belajar XI IPS

Dalam pratindakan yang dilakukan di kelas XI IPS SMA Nasima Semarang dalam kegiatan observasi masih banyak dijumpai peserta didik yang pasif dalam kegiatan pembelajaran. Kurangnya partisipasi peserta didik tersebut dikarenakan kurangnya keberanian dan rasa percaya diri peserta didik. Hal ini lah yang juga berpengaruh langsung terhadap 
proses pembelajaran. hasil belajar peserta didik masih rendah, peserta didik yang telah memenuhi Kriteria Ketuntasan Minimal (KKM) sebanyak 10 peserta didik dari 19 peserta didik, bila diprosentasekan sebesar 52,63\%. Peserta didik yang tidak memenuhi batas KKM sebanyak 9 peserta didik dari 19 peserta didik yaitu sebesar 47,37\%. Rata-rata kelas pada tes awal (pratindakan) peserta didik kelas XI IPS sebesar 68,68.

Pembelajaran sosiologi yang telah dilaksanakan pada siklus I ini mengharapkan peserta didik mampu menguasai materi penyebab dan dasar stratifikasi sosial. Setelah selesai melaksanakan siklus pertama, peneliti mengumpulkan data berupa hasil evaluasi peserta didik pada siklus I. Dengan ketuntasan peserta didik mencapai KKM berjumlah peserta didik yang telah mencapai ketuntasan belajar sebanyak 15 dari 19 peserta didik kelas XI IPS SMA Nasima Semarang dengan nilai rata-rata kelas yaitu 78,1. Kriteria Ketuntasan Minimal (KKM) untuk mata pelajaran sosiologi adalah 75 untuk SMA Nasima Semarang. Secara prosentase ketuntasan peserta didik dengan jumlah 15 peserta didik adalah 78, $95 \%$ sedangkan ketidaktuntasannya 21,05\%. Dari hasil analisis tersebut perlu adanya perbaikan pada siklus II

Pembelajaran sosiologi yang telah dilaksanakan pada siklus II mengharapkan peserta didik mampu menguasai materi sifat dan fungsi stratifikasi sosial. Berdasarkan analisis tes kognitif pada siklus II, diketahui bahwa seluruh peserta didik mencapai KKM yaitu sebanyak 19 peserta didik dari 19 peserta didik kelas XI IPS SMA Nasima Semarang dengan nilai rata-rata kelas yaitu 89,68 dengan prosentase $100 \%$. Hal tersebut menandakan bahwa model pembelajaran problem based learning dengan menggunakan microsoft 365 mampu meningkatkan hasil belajar peserta didik di kelas XI IPS SMA Nasima Semarang.

\section{DISKUSI}

Interaksi antara guru dengan peserta didik dalam suatu pembelajaran harus mampu memunculkan partisipasi peserta didik agar dapat mendukung keberhasilan suatu pembelajaran. Untuk mendapatkan hasil belajar yang maksimal guru harus menciptakan suasana belajar yang mampu 
Habitus: Jurnal Pendidikan Sosiologi dan Antropologi

Vol. 4 No. 1 Tahun 2020 hal. 70-79

ISSN: 2597-9264

mendukung semangat atau motivasi belajar belajar dari peserta didik itu sendiri. Hal tersebut dilakukan agar mendapatkan suasana belajar yang kondusif dan mampu mempermudah peserta didik dalam menerima materi yang disampaikan oleh guru.

Dalam penelitian terdahulu yang mengkaji tentang model pembelajaran problem based learning untuk meningkatkan motivasi dan hasil belajar peserta didik. Nisaul 'Azmi Hajar (2015) melakukan penelitian dengan judul "Penerapan Model Pembelajaran Problem Based Learning (PBL) Untuk Meningkatkan Hasil Belajar Siswa Kelas X-3 Pada Mata Pelajaran Sosiologi SMA Negeri Kebakkramat Tahun Ajaran 2015/2016". Penelitian ini bertujuan untuk meningkatkan hasil belajar siswa kelas X-3 SMA Negeri Kebakkramat tahun ajaran 2015/2016 pada mata pelajaran sosiologi melalui penerapan model pembelajaran Problem Based Learning (PBL). Jenis penelitian ini adalah Penelitian Tindakan Kelas (PTK) yang dilaksanakan dalam dua siklus dengan 3 kali pertemuan setiap siklusnya. Setiap siklus terdiri dari beberapa tahap yaitu perencanaan, pelaksanaan tindakan, observasi dan refleksi. Siklus pertama dan kedua membahas materi pokok penyimpangan sosial. Subjek dalam penelitian ini adalah siswa kelas X-3 SMA N Kebakkramat Tahun Ajaran 2015/2016 yang terdiri dari 38 siswa. Teknik utama dalam pengumpulan data dilakukan dengan cara tes dan observasi, sementara teknik pendukung dengan menggunakan wawancara, dan dokumentasi.Hasil penelitian menunjukkan bahwa penerapan model pembelajaran Problem Based Learning (PBL) dapat meningkatkan hasil belajar siswa kelas X-3 mulai dari pratindakan, siklus I dan siklus II, yaitu 67,65 pada tahap pratindakan meningkat menjadi 75,65 pada siklus I dan kembali meningkat menjadi 80,86 pada siklus II. Simpulan penelitian ini adalah penerapan model pembelajaran Problem Based Learning (PBL) dapat meningkatkan hasil belajar sosiologi siswa kelas X-3 SMA N Kebakkramat.

Berbeda dengan penelitian diatas, pada penelitian ini penerapan model pembelajaran Problem Based Learning dengan menggunakan microsoft 365 berdasarkan berbagai masalah yang telah ditemukan peneliti dalam kegiatan 
observasi. Masalah tersebut antara lain kurangnya minat belajar peserta didik terhadap mata pelajaran sosiologi juga menjadi suatu masalah yang membuat rendahnya partisipasi peserta didik dalam proses pembelajaran. Selain itu, sebenarnya terdapat beberapa peserta didik yang sudah menguasai materi yang diajarkan, akan tetapi rendahnya partisipasi aktif mereka disebabkan karena mereka tidak memiliki keberanian untuk menyampaikan pendapat mereka sendiri. Penggunaan model pembelajaran berperan sangat penting untuk kelanjutan proses pembelajaran, karena dengan menggunakan berbagai model mampu membuat proses pembelajaran lebih bervariasi. Penggunaan model tersebut juga sangat membantu untuk membuat peserta didik aktif dalam proses pembelajaran, sehingga peserta didik pun menjadi mudah untuk memahami materi yang disampaikan oleh guru. Penerapan model Problem Based Learning dengan menggunakan microsoft 365 ini mampu meningkatkan hasil belajar peserta didik dalam mata pelajaran sosiologi sesuai dengan hasil penelitian di kelas XI IPS SMA Nasima dari pratindakan hingga siklus II. Pada tahap pra tindakan adalah $52,63 \%$ dengan nilai rata-rata kelas 68,68. Pada siklus I nilai ketuntasan klasikal peserta didik menjadi $78,95 \%$ dengan ratarata kelas 78,1 , siklus II nilai ketuntasan klasikal peserta didik menjadi 100\% dengan rata-rata kelas 89,68. Di sini terlihat bahwa peningkatan terjadi pada setiap siklusnya.

\section{KESIMPULAN}

Berdasarkan hasil penelitian, dapat di simpulkan bahwa terjadi peningkatan hasil belajar (kognitif) siswa. Sebelum diterapkannya model pembelajaran problem based learning menggunakan microsoft 365 dilakukan penilaian pratindakan dengan hasil ketuntasan klasikal peserta didik yaitu 52,63\%. Pada silkus I, setelah dilakukan penerapan model pembelajaran tersebut meningkat menjadi $79,26 \%$ yang memiliki tingkat keaktifan belajar tinggi. Pada siklus II, keaktifan belajar siswa kembali meningkat sebanyak $89,31 \%$ memiliki tingkat keaktifan belajar tinggi. Dan peningkatan presentase hasil belajar siswa terutama aspek kognitif mengalami peningkatan. Sebelum diterapkannya model 
Habitus: Jurnal Pendidikan Sosiologi dan Antropologi

Vol. 4 No. 1 Tahun 2020 hal. 70-79

ISSN: 2597-9264

pembelajaran tipe tari bambu, nilai rata rata kelas mencapai 68,68 ( ketuntasan 52,63\%) dari KKM 75. Setelah dilakukan penerapan model pembelajaran problem siswa yang mencapai batas KKM meningkat menjadi sebanyak 15 siswa (78, 95\%). Pada siklus II, hasil belajar siswa (kognitif) kembali mengalami peningkatan nilai rata - rata meskipun yaitu menjadi 89,68 dimana seluruh siswa yang mencapai batas KKM yaitu sebanyak 19 siswa (100\%). Sehingga implikasi based learning pada siklus I, nilai rata rata kelas mengalami peningkatan menjadi 78,01 dimana

teoritis dari penelitian ini bahwasanya model pembelajaran problem based learning dengan menggunakan office 365 dapat diterapkan pada mata pelajaran sosiologi materi perbedaan, kesetaraan, dan harmoni sosial, yang memiliki permasalahan rendahnya hasil belajar peserta didik terutama aspek kognitif.

\section{Daftar Pustaka}

Anies. (2003). Problem-Based Learning, http://www.suara merdeka.com/harian/ 0304/28/kha2.html.(28 April 2003).

Ghofur, Abdul., (2004. Pedoman Umum Pengembangan Penilaian Berbasis Kompetensi, Yogyakarta: Depdiknas Dikdasmen Dikmenum.

Hajar, Nisaul 'Azmi,. (2015). Penerapan Model Pembelajaran Problem Based Learning (PBL) untuk Meningatkan Hasil Belajar Siswa Kelas X-3 Pada Mata Pelajaran Sosiologi SMA NEGERI Kebakkramat Tahun Ajaran 2015/2016. Jurnal Sosialitas Pendidikan Sosiologi Antropologi Fakultas Keguruan dan Ilmu Pendidikan Universitas Sebelas Maret, Volume 7 Nomor 2 (2015).

Iskandar. (2012). Penelitian Tindakan Kelas. Jakarta Selatan : GP Press Group.

Martinis, Yamin. (2013). Paradigma Baru Pembelajaran. Jakarta : Referensi.

Moleong. J. Lexy. (2004). Metodologi Penelitian Kualitatif. Bandung: PT Remaja Rosdakarya. 
Trianto. (2011). Penelitian Tindakan Kelas. Jakarta : Prestasi Pustaka Raya. 